\title{
Dreaming is a Must, Despite the Current Crisis
}

On the $1^{\text {st }}$ of June, I was inaugurated as the $21^{\text {st }}$ president of the Brazilian Chemical Society (SBQ). Under normal conditions, to be the SBQ president would already be a challenge, given the significance of this society for the Brazilian chemical community and its importance among the national scientific societies. However, at this moment this challenge has been extraordinarily amplified. When I accepted to be a candidate, in the beginning of 2018, we were worried about the science funding crisis ${ }^{1,2}$ and a somewhat pervasive discredit of science. In 2019, that situation deepened, along with the more marked emergence of pre- and antiEnlightenment attitudes, as well as of environmental crises. ${ }^{3}$ In 2020, the Covid-19 pandemic took us to another level of crisis, profoundly affecting our lives, our routines, and bringing us losses in every way, sometimes very personal. In a few months, the crisis became economic, political, and sanitary. Given the virulence that Covid-19 can assume, social distancing is the best initial strategy to deal with the pandemic. In fact, that was the reason my inauguration as SBQ president took place in an unusual, virtual general assembly, which I hope will be the only one in the history of SBQ. Fortunately, science has been responding quickly, and thus gradually a better understanding of the different aspects of Covid-19 is being gained, with the emergence of treatments and the development of vaccines at an accelerated pace. In fact, it is worth noting that many Brazilian chemists, most of them SBQ members, have been participating in this extraordinary effort (see, e.g., references 4-7), bringing us great pride. That has contributed to a renewed appreciation of science by the public, which is deeply welcomed.

In addition to the enormous challenge, it is an honor to serve as SBQ president. At this point, I will borrow from a point made by President Barack Obama in the end of 2017: a president is just one more participant in a relay race, i.e., a collective endeavor. After receiving the baton from my predecessor, Prof Norberto Peporine Lopes, I am only starting another leg of the successful relay race initiated by the esteemed Prof Simão Mathias, when the Society was founded in 1977. Thus, besides being an honor, it is a very big responsibility to assume the presidency of SBQ. However, as it has happened with the noble colleagues that preceded me, I will count on the support of the other members of the Board and the advice of the members of the Advisory Council.

In 2018, as a candidate, I set out to contribute to adjust the SBQ activities to the times we live/will live, listening to the members on how to better meet their needs. I confess that then I also chose to use the verb in the future tense, "we will live", to be open to new challenges, new opportunities. I thought that, perhaps, some new way of communication could emerge. A pandemic emergency never crossed my mind (despite warnings from several scientists); at the time, I also thought it was impossible to have the President of Brazil we have today. There is no doubt, predicting the future is a very difficult task. Yet here we are, in the midst of an economic, political, and health crisis, mutating week by week. In this context, it is very important that the SBQ continues to take positions in defense of Science and its valorization, either to society as a whole or to different governmental bodies. It is also very important that SBQ remains focused on the needs of its members, providing them with relevant services, especially those aimed at the development, teaching, and application of chemistry, with adjustments to the new circumstances. At the same time, whenever possible, we will seek to further increase the possibilities for the involvement of the members and the professionalization of our Society.

Lastly, I would like to stress that in times of crisis, besides surviving, it is most important for all of us to deeply think about, dream of, and prepare for the future. Things will certainly chance and improve, the sooner the better, and the future belongs to those that are prepared to embrace the opportunities brought out by it.

\section{Romeu C. Rocha-Filho ${ }^{\circledR}$ \\ President of the Brazilian Chemical Society Universidade Federal de São Carlos São Carlos-SP, Brazil}

\section{References}

1. Zarbin, A. J. G.; J. Braz. Chem. Soc. 2016, 27, 1705.

2. Zarbin, A. J. G.; J. Braz. Chem. Soc. 2018, 29, 1981.

3. Lopes, N. P.; de Freitas, R. P.; Rocha Filho, R. C.; J. Braz. Chem. Soc. 2019, 30, 681.

4. Sodré, F. F.; Brandão, C. C. S.; Vizzotto, C. S.; Maldaner, A. O.; Quim. Nova 2020, 43, 515.

5. Lima, M. L. S. O.; Almeida, R. K. S.; da Fonseca, F. S. A.; Gonçalves, C. C. S.; Quim. Nova 2020, 43, 668.

6. Sequinel, R.; Lenz, G. F.; da Silva, F. J. L. B.; da Silva, F. R.; Quim. Nova 2020, 43, 679.

7. Clososki, G. C.; Soldi, R. A.; da Silva, R. M.; Guaratini, T.; Lopes, J. N. C.; Pereira, P. R. R.; Lopes, J. L. C.; dos Santos, T.; Martins, R. B.; Costa, C. S.; de Carvalho, A. N.; daSilva, L. L. P.; Arruda, E.; Lopes, N. P.; J. Braz. Chem. Soc. 2020, 31, 1552. 